\title{
Lough Neagh: the site of a Cenozoic pull-apart basin
}

\author{
MARTYN F. QUINN \\ British Geological Survey, Murchison House, West Mains Road, Edinburgh, EH9 3LA \\ (email: $\underline{m f q @ b g s . a c . u k)}$
}

\section{Synopsis}

The Lough Neagh Basin in Northern Ireland is the site of a Cenozoic depocentre defined by gravity measurements and a thick succession of Paleocene basaltic lavas and Upper Oligocene clays. Much of the Cenozoic outcrop is concealed by Lough Neagh, but the rhombic outline of the lough provides some indication of the underlying structural control of the depocentre. Several authors have inferred that a Cenozoic pull-apart basin lies within the Lough Neagh area and suggest it is one of a number of transtensional basins, including the Bovey and Petrockstow basins in SW England, associated with NW to NNW-trending strike-slip fault zones. Solid geology maps and gravity data show that the structure of the Lough Neagh Basin is dominated by a segmented, orthogonal pattern of offset NNW and NE-trending faults. It is proposed that pull-apart basin formation took place in the Mid-Paleocene by dextral movement on these offset faults. The potential link between strike-slip tectonics and Cenozoic volcanism in the north of Ireland is briefly considered.

\section{Introduction}

The nature and mode of formation of pull-apart basins have been the subject of study by many workers, and examples have been described worldwide (for example, Aydin \& Nur 1982; Mann et al. 1983; Sylvester 1988; Bartholomew et al. 1993; Oudmayer \& de Jager 1993; Dooley et al. 1999; Reijs \& McClay 2003). Pull-aparts are generally defined as zones of extension produced at bends or step-overs in a strike-slip fault system. Some of the features characteristic of mapped pull-apart basins worldwide are:

- their often rhombic shape

- $\quad$ their typically steep sides

- $\quad$ their marked depths

- their thick sedimentary successions

In the British Isles, Cenozoic pull-apart basins have been described in the Southern North Sea (Smith 2004), in the Bristol Channel (the Lundy pull-apart basin, Arthur 1989), and in SW England where the Bovey and Petrockstow basins were formed by Early Cenozoic strike-slip reactivation of the NW-trending Sticklepath-Lustleigh Fault (Fig. 1; Holloway \& Chadwick 1986; Bristow \& Robson 1994). This fault forms part of a NW- to NNW-trending system of strike-slip faults that transect western Britain and Ireland and which have a history of 
reactivation during the Permian, Mesozoic and Cenozoic (Lake \& Karner 1987; Ziegler 1990).

From the presence of a combination of the features listed above, together with its location on a NNW-trending fault zone, several workers have inferred a pull-apart origin for the Cenozoic depocentre situated within the Lough Neagh Basin (Jenner 1981; Parnell et al. 1989; Ziegler 1990). However, the nature of this pull-apart basin has not previously been described in detail. The shape of the basin, which probably contains the thickest preserved Cenozoic succession in onshore Ireland, is defined by gravity data which are constrained by borehole information (Fig. 2; Carruthers et al. 1987; British Geological Survey 1997). Much of the Cenozoic outcrop is concealed by Lough Neagh itself which, with an area of $396 \mathrm{~km}^{2}$, is the largest lake in the British Isles.

Gravity data provide complete representation of regional Bouguer anomaly variations in Northern Ireland. They consist of a total of about 11,500 observation points whose distribution was largely governed by the road network, but also includes data from the bottom of Lough Neagh (Carruthers et al. 1987). Although the shape and trends of the Permo-Triassic and Cenozoic basins can be delineated, depths to the Permo-Triassic beneath Lough Neagh are sensitive to the thickness assumed for Lough Neagh Group. The thicknesses assumed by Carruthers et al. (1987) were constrained by local drilling and seismic surveys.

This paper describes the characteristics of the Cenozoic depocentre situated within the Lough Neagh Basin using information derived from boreholes, mapped faults and geophysical data. These defining characteristics, combined with the regional structural setting, have enabled the development of the basin during the Cenozoic to be described. Finally, the implications of these observations for the regional geology of the Lough Neagh area are discussed.

\section{Geological setting}

The NE-trending Lough Neagh and Larne basins (and the Rathlin Trough to the north of the Highland Border Ridge) comprise the onshore part of the Ulster Basin (Figs. 1 \& 3; Ziegler 1990; Naylor 1992). The Lough Neagh and Larne basins overlie metamorphic basement of the Midland Valley Terrane (Anderson et al. 2004) in an area of prolonged strike-slip faulting between the Southern Upland Fault and the Highland Boundary Fault (Figs. 1 \& 3; Phillips 2001). In Northern Ireland, the Southern Upland Fault forms the SE boundary between the

Midland Valley and Southern Upland terranes (Floyd 1994), whereas to the NW, the Highland Boundary Fault defines the SE boundary of the Dalradian Highland Border Ridge 
(Figs. $1 \&$ 3). Both these fault zones originated during the Caledonian Orogeny (Floyd 1994; Phillips 2001). Evidence from the Midland Valley of Scotland suggests that these Caledonian basement faults were subsequently reactivated, both in a dip-slip and strike-slip sense, during Carboniferous basin formation and that Early Carboniferous sedimentation was mainly focused between these major faults (Read 1988; Anderson et al. 1995; Ritchie et al. 2003). During the Late Carboniferous this NE-SW control on sedimentation may have been replaced by subsidence along NNW-SSE trends (Anderson et al. 1995). The Late Carboniferous also marked the initiation of the Ulster Basin that continued in its development throughout the Permian and Mesozoic (Fig. 1; Ziegler 1990).

Following consolidation of the Variscan fold belt during the Late Carboniferous and Early Permian, an eruptive volcanic episode occurred in the Early Permian over much of NW Europe. Intermediate to basic lavas and tuffs, tuffaceous siltstones, and sandstones, proven in the Larne No.2 borehole (Fig. 3; Penn et al. 1983), succeed thin Early Permian breccias and form part of this widespread Lower Permian volcanic province (Wilson et al. 2001).

In Northern Ireland, Permian and Mesozoic sediments occur in NE-SW trending basins (Parnell et al. 1989) reaching a maximum depth of $3.5 \mathrm{~km} \pm 0.5 \mathrm{~km}$, with some control being exercised by a NNW-trending structural component (Illing and Griffith 1986; Carruthers et al. 1987). Syndepositional fault activity along NE-SW trending faults has been interpreted by Anderson et al. (1995) from local mapping. It has also been cited by Naylor et al. (2003) to explain thickness differences in Triassic and Upper Permian sedimentary successions proved in the Annaghmore-1 and Ballynamullan-1 boreholes located on the north shore of Lough Neagh. An area of Permo-Triassic thinning separates the NE-SW trending Lough Neagh and Larne basins and suggests that although following a common Caledonian trend, they generally formed separate depocentres during the Mesozoic (Fig. 3; Carruthers et al. 1987; Shelton 1997).

In Late Permian, Rhaetian, Liassic and Late Cretaceous times Northern Ireland was subjected to a series of marine incursions, each more extensive than the previous one. The final, Senonian, transgression may have covered all of Ireland, though the Highland Border Ridge remained a positive feature throughout the Mesozoic with sediments either thin or absent (Wilson et al. 2001).

Latest Cretaceous and earliest Cenozoic uplift and erosion resulted in a differentially eroded chalk surface with solution hollows and a patchy 'clay with flints' residual deposit. Paleocene 
volcanic activity began explosively with voluminous outpourings of a silicic pyroclastic flow resulting in deposition of an ignimbrite whose outcrop indicates a regional extent of at least $30 \mathrm{~km}$ (Mitchell et al. 1999). The ignimbrite has a relatively constant thickness $(\sim 1 \mathrm{~m})$ and contains abundant flints, suggesting the ash flowed over a flat weathered Cretaceous landscape (Mitchell et al. 1999). This was followed by the eruption of basaltic lavas of the Antrim Lava Group between 61 and 58 Ma ago (Thompson 1985; Preston 2001). The Antrim Lava Group has been subdivided lithologically into the Lower and Upper Basalt Formations. These are separated by a succession containing weathering products of the earlier eruptions, and acid volcanics that probably mark the end of the first cycle of volcanism (Preston 2001). The intra-basaltic Tardree Rhyolites have been dated at 58.4 $\pm 0.7 \mathrm{Ma}$ (Earliest Thanetian) by Gamble et al. (1999), and thus date the Lower Basalt Formation as older than 58.4 Ma (MidPaleocene). Cessation of igneous activity was followed, in the Mid-Palaeogene (end Paleocene to Oligocene), by NNE-SSW compression resulting in NNW-trending dextral and NE-trending sinistral faulting of the lavas and structural inversion (Geoffroy et al. 1996; Mitchell 2004).

During the Late Oligocene (Chattian), sediments of the Lough Neagh Group were deposited in two separate areas in NE Ireland. In the Ballymoney area (Fig. 3), over $500 \mathrm{~m}$ of Lough Neagh Group sediments have been proved north of the Tow Valley Fault. The thick succession is thought to have been deposited in a pull-apart basin controlled by sinistral movement on the Tow Valley Fault and dilation of NNW-trending fractures (Parnell et al. 1989; Mitchell 2004). In the Lough Neagh area, the basin fill, consisting of mainly palecoloured clays and silts with beds of sand and lignite, reaches a maximum known thickness of $381 \mathrm{~m}$ in the Derryinver Borehole (Fig. 3; base of Group not penetrated) and covers an area of about $500 \mathrm{~km}^{2}$, of which $300 \mathrm{~km}^{2}$ underlie the lough (Fig. 3; Wilson 1972; Wilkinson et al. 1980; Mitchell 2004).

A large number of mapped NW- to NNW-trending strike-slip faults transect Western Britain from the Western Approaches to north of Shetland and have influenced the structural and sedimentary development of the region. For instance, the late Mesozoic-Cenozoic development of the St. George's Channel Basin is linked to reactivation of the bounding Sticklepath-Lustleigh and Codling faults (Fig. 1; Williams et al. 2005). The Codling Fault dissects the Kish Bank Basin and may continue, possibly right-stepping, as the Newry and Bann faults located SW of Lough Neagh in the Ulster Basin (Fig. 1; Cunningham et al. 2004). 


\section{The Lough Neagh Basin}

Variation in thickness of Palaeogene fill

Evidence for the existence of an area of subsidence within the Lough Neagh Basin during eruption of the Antrim Lava Group comes from borehole information (e.g. Preston 2001) and examination of zeolite distribution within the basalt pile (Walker 1995). The present-day preserved thickness and extent of the Antrim Lava Group is a function of original thickness and amount of subsequent erosion. The flood basalts cover an area of over $4300 \mathrm{~km}^{2}$, probably less than half their original extent (Walker 1995). Their maximum thickness is unknown, though preserved thicknesses of $780.2 \mathrm{~m}$ in the Langford Lodge Borehole and $770.1 \mathrm{~m}$ in the Ballymacilroy Borehole have been proved (Fig. 3; Preston 2001). Using data from studies of zeolite distribution in the basaltic pile, Walker (1995) calculated that the original lava thickness at Langford Lodge was about $1060 \mathrm{~m}$.

On the north shore of Lough Neagh, boreholes Annaghmore-1 and Ballynamullan-1 proved $342.6 \mathrm{~m}$ and $463.3 \mathrm{~m}$, respectively, of the Antrim Lava Group. The Antrim lavas penetrated at these two locations probably represent an eroded succession of the Lower Basalt Formation (Fig. 3; Naylor et al. 2003). Measured thicknesses of the complete, uneroded, Lower Basalt Formation of $531 \mathrm{~m}$ in the Langford Lodge Borehole and $427 \mathrm{~m}$ in the Ballymacilroy Borehole have been recorded (Fig. 3; Manning et al. 1970; Preston 2001). Thus, although total preserved thicknesses of the Antrim Lava Group differ by only $10 \mathrm{~m}$ between the Langford Lodge and Ballymacilroy boreholes, the uneroded Lower Basalt Formation thickness differs by more than $100 \mathrm{~m}$; a $20 \%$ increase in thickness over a distance of about 20 km. Tomkeieff (1964) produced an isopachyte map of the Lower Basalt Formation, reproduced in Shelton (1997), that illustrates thickening towards the centre of Lough Neagh (Fig. 4; Preston 2001). Shelton (1997) noted that subdivision of the Antrim Lava Group at outcrop is difficult, but confirmed the gross thickening trends reported by previous authors. Crucially, the attitude of zeolite zones within the basalts shows that the lavas thicken downdip towards the centre of the Lough Neagh Basin (Walker 1995).

A characteristic common to both the Bovey and Petrockstow pull-apart basins in SW England and the Lough Neagh Basin, is the thickness of their Palaeogene sedimentary fill. Geophysical measurements over the Bovey Basin suggest that $1000 \mathrm{~m}$ of Palaeogene sediments may be present, and a borehole drilled by the British Geological Survey in the centre of the Petrockstow Basin proved $660 \mathrm{~m}$ of sands and silts (Bristow \& Robson 1994). At Lough Neagh, Carruthers et al. (1987) assumed a maximum thickness of $500 \mathrm{~m}$ of 
Palaeogene clays, comprising the Lough Neagh Group, although the greatest known thickness is $381 \mathrm{~m}$ proved by the Derryinver Borehole that terminated within these sediments (Fig. 3; Mitchell 2004). The Washing Bay Borehole at the SW corner of the lough penetrated $351 \mathrm{~m}$ of the Lough Neagh Group before terminating in the underlying Antrim Lava Group (Fig. 3; Mitchell 2004). The Lough Neagh Clays are of Upper Oligocene (Chattian) age (Wilkinson et al. 1980). Coarse sediments penetrated in the vicinity of faults may represent screes formed adjacent to faults active during deposition of the Lough Neagh Group (Parnell et al. 1989). The Lough Neagh Group, Bovey Formation and Petrockstow beds have a marked sedimentological similarity (Wilkinson et al. 1980). However, the source of the Lough Neagh Group has been shown to be dominantly eroded Paleocene basalts (Mitchell 2004).

\section{Orientation of the Mesozoic and Cenozoic basins}

The Ulster Basin, comprising, in part, the Lough Neagh and Larne basins (Figs. 1 \& 3), is a long-established depocentre and has sedimentary successions ranging in age from at least the Carboniferous through the Mesozoic and Cenozoic to the present day (Shelton 1997).

NE-trend in the Mesozoic. Isopach maps, compiled from borehole data and supplemented by geophysical evidence, have been published for the Triassic Sherwood Sandstone Group, the Mercia Mudstone Group, the Lower Lias and the Cretaceous Ulster White Limestone (McCaffrey \& McCann 1992). All these maps show NE- to ENE-trending depocentres within the Lough Neagh and Larne basins SE of the Highland Border Ridge. The form and approximate depths of the Mesozoic basins that underlie the Antrim Lava Group have been modelled using gravity measurements; these confirm the general NE trend (Fig. 4; Carruthers et al. 1987; Reay 2004, figure 19.9).

NW to NNW trend in the Mid-Paleocene. Examination of average flow thickness $(7.05 \mathrm{~m})$ of the Paleocene basaltic Antrim lavas enabled Walker (1995) to calculate that they were erupted onto a surface with dips of less than $2^{\circ}$. Walker (1995) notes that present-day dips of the basaltic lavas are between $5^{\circ}$ and $15^{\circ}$ and the dip is centripetal delineating a NW- to NNWtrending saucer shaped structure. Lower Basalt Formation thickness, mapped by Tomkeieff (1964) and reproduced in Shelton (1997), also suggests a NW to NNW trend to the basin (Fig. 4).

NNE trend in the Late Oligocene. The orientation of the basin containing the Upper Oligocene Lough Neagh Group is best delineated from examination of the residual Bouguer 
anomaly data (Figs. 2 \& 4; Carruthers et al. 1987). This shows two separate elongate ENEtrending Cenozoic depocentres lying diagonally opposite each other and separated by a ridge. This arrangement has been noted in other examples of pull-apart basins (Mann et al. 1983) and is discussed later. These two separate depocentres together form a NNE trend (Figs. $2 \&$ 4; British Geological Survey 1997).

In summary, the Cenozoic development of the Lough Neagh Basin is defined by thick successions of more than $1000 \mathrm{~m}$ of Paleocene flood basalts and Upper Oligocene clays. The changes in the orientation of the approximately coincident Mesozoic, Paleocene and Oligocene basins in the Lough Neagh area are indicative of changes in the regional stress regime that affected northern Ireland through time and resulted in the initiation and development of the Cenozoic pull-apart structure.

\section{Faulting}

Several authors (Wilson 1972; Parnell et al. 1989; McCann 1991; Geoffroy et al. 1996; Shelton 1997; Preston 2001) have described the faulting associated with the Lough Neagh Basin. For instance, Wilson (1972) noted that, following extrusion of the lavas, widespread warping of the crust led to the general synclinal form of the lava plateau and that this was accompanied by significant faulting. Shelton (1997) suggested that accommodation space for the Upper Oligocene Lough Neagh Group was facilitated by faulting. Naylor (1992) stated that 'Lough Neagh Group sedimentation was probably controlled by NE-SW and NNW-SSE fractures in an extensional or strike-slip setting'. Geoffroy et al. (1996) record a Paleocene syn-magmatic phase of normal and strike-slip faulting, followed by a post-magmatic phase of strike-slip faulting and structural inversion in a compressional strike-slip regime between the end of the Paleocene and the Oligocene, this being succeeded by NW-SE extension in the Oligocene.

The locations of the main mapped faults around Lough Neagh are shown in Figure 3. However, the thick Paleocene lavas of the Antrim Lava Group conceal the earlier successions and structure. Some of the observed aeromagnetic and gravity lineaments discussed by McCann (1991), and gravity lineaments interpreted by Carruthers et al. (1987), have been deduced to be continuations of these mapped faults (Figs. 2, $3 \& 5$ ).

The two main fault trends recognized in the Lough Neagh Basin are NE to ENE and NNW (Figs 2 \& 3; McCann 1991). The mapped faults (Fig. 3; GSNI 1997), and faults interpreted from aeromagnetic and gravity lineaments (Fig. 2), together show a dominantly orthogonal 
relationship (Walker 1995). It is suggested that interaction between the two fault sets controlled the formation and location of the Cenozoic pull-apart structure.

The NNW-trending fault zone. This fault zone is represented to the south of Lough Neagh by the mapped Bann, Newry, Camlough and Markethill faults (Figs. 3 \& 5). The Camlough Fault has been active since Late Paleocene times, as proved by a mapped $2 \mathrm{~km}$ of dextral strike-slip movement on the Slieve Gullion central igneous complex that was emplaced at $56.5 \pm 1.3 \mathrm{Ma}$ (Gamble et al. 1999). Though not mapped as a continuous structure (GSNI 1997), the Camlough Fault is predicted to continue in a NNW direction, becoming the Markethill Fault (GSNI 1985), near the SW corner of Lough Neagh (Figs. 3 \& 5). The Newry Fault is parallel to, and $5 \mathrm{~km}$ to the east of, the Camlough Fault. This fault offsets the Devonian Newry Granodiorite dextrally by $2 \mathrm{~km}$ (Fig. 3; GSNI 1997), and is also predicted to continue to the SW corner of Lough Neagh as the Bann Fault (Figs. 3 \& 5).

If Lough Neagh is interpreted to mark the location of a Cenozoic pull-apart basin (Figs. 3 \& 5), it is predicted that NNW-trending faults should also occur offset to the right beneath the lough in order for a pull-apart to form at this location. Offsetting of NNW-trending faults prior to formation of the Cenozoic pull-apart could have occurred during initial development of the faults, or by dextral movement on some of the NE- to ENE-trending faults that transect the Lough Neagh Basin. The offset continuation of the NNW-trending fault is predicted to be present close to the north-eastern edge of the lough, following the locations of NNW-trending aeromagnetic and gravity anomalies that eventually join with a mapped fault, the Loughguile Fault, to the north (Figs. 2, 3 \& 5; Reay 2004).

The NE-trending faults. Due to concealment by the Antrim Plateau Lavas and Lough Neagh, it is not possible to trace any of the ENE-trending faults continuously beneath the Lough Neagh pull-apart basin (Fig. 3; GSNI 1997). However, McCann (1991) observed two ENEtrending gravity ridges extending beneath the lough, where they are dextrally offset by about $4 \mathrm{~km}$ (Fig. 2). It is possible that the ridges represent transfer linkage between two en echelon ENE-trending faults. However, the mapped dextral displacement at Slieve Gullion to the south gives weight to the case that the offset observed on these gravity ridges is indirect evidence for dextral movement beneath Lough Neagh and suggests that ENE-trending faults such as the Sixmilewater Fault, mapped from the Irish Coast just NW of Larne Lough towards the east side of Lough Neagh, and the NE-trending Portmore Fault to the south, could be dextrally offset beneath Lough Neagh (Figs. 3 \& 5; GSNI 1994; GSNI 1997). 
In summary, the pattern of faults transecting the Lough Neagh Basin is complex and partially obscured by the Antrim Lava Group and Lough Neagh. Several of the faults in the area show mapped evidence of Cenozoic dextral movement and observations from potential field data provide indirect evidence. Both the NNW- and NE- to ENE-trending faults display a segmented nature. The faults, both mapped and predicted by aeromagnetic and gravity data, have trends and styles conducive to formation of a pull-apart basin (Figs. $3 \& 5$ ).

\section{Length-breadth ratio}

Aydin and Nur (1982), in a study of 70 well-defined transpressional and transtensional rhombic structures, illustrated the wide range of dimensions that can exist. Although the precise dimensions of the Cenozoic Lough Neagh Basin are difficult to quantify, there is no doubt that the length-breadth ratio of the pull-apart is low. The basin is interpreted to be 22 by $18 \mathrm{~km}$ (north-south to east-west) in size (Fig. 5), giving an aspect ratio of 1.2:1. By comparison, the Petrockstow (6 km x $1.5 \mathrm{~km})$ and Bovey basins $(7 \mathrm{~km} \times 5 \mathrm{~km})$ have aspect ratios of 4:1 and 1.4:1 respectively (Bristow \& Robson 1994).

\section{Alignment of depocentres}

A residual Bouguer anomaly map for the Lough Neagh Cenozoic basin shows two diagonally arranged gravity lows separated by a ridge located beneath Lough Neagh (Figs. $2 \& 4$ ). These gravity lows may represent depocentres (up to 500 m thick) of Lough Neagh Group sediments (Carruthers et al. 1987). Depocentres, often diagonally arranged across the floor of a pullapart basin and separated by a shallow sill, have been documented in several examples worldwide (Mann et al. 1983). The depocentres are sometimes fault bounded, and are located at distal ends of the pull-apart basins.

\section{Regional setting and Cenozoic development of the Lough Neagh pull-apart basin}

It is well documented that the application of regional stresses oblique to fault trends gives rise to strike-slip reactivation (Lake \& Karner 1987; Ziegler 1990; Bartholomew et al. 1993; Dooley et al. 1999). A complex regional system of wrench faults extends north of the Variscan Front to include the NW continuation of the Sticklepath-Lustleigh Fault (Ruffell \& Carey 2001), the NW-trending Codling Fault and the NNW-trending Bann, Newry, Camlough and Markethill faults. Offsets along the segmented Sticklepath-Lustleigh Fault system controlled the location of the Early Cenozoic Bovey, Petrockstow (Holloway \& Chadwick 1986; Bristow \& Robson 1994) and Lundy pull-apart basins (Arthur 1989). A similar situation occurs in Northern Ireland, where offsets in NNW-trending faults that transect the 
area have controlled the location of the Cenozoic Lough Neagh pull-apart basin (Figs. 1, 3 \& $5)$.

From the Late Cretaceous, Laramide collision between Africa and Europe produced stresses that induced NW-SE compression and far-field dextral reactivation of favourably-oriented strike-slip faults such as the Sticklepath-Lustleigh fault system (Lake \& Karner 1987; Ziegler 1990). At the same time volcanic activity, associated with rifting in the Arctic/North Atlantic region, increased and peaked in the Late Paleocene, coinciding with the Laramide phase of intra-plate compressional deformation (Ziegler 1990). Mild Mid-Paleocene inversion has been recorded in the Celtic Sea Basin and elsewhere west of Britain (Ziegler 1987). It is in this regional context that the formation of the Cenozoic Lough Neagh pull-apart basin is envisaged to have taken place (Fig. 6).

It is proposed here that the segmented, right-stepping NNW-trending faults underwent significant dextral movement in the Mid-Paleocene centred on Lough Neagh (Figs. 5 \& 6). The NE- to ENE-trending faults crossing the basin may also have experienced Early Cenozoic reactivation, and would have contributed to the formation of the pull-apart (Fig. 5; Parnell et al. 1989). The formation of a pull-apart basin from right-stepping controlling faults can only occur when the movement on them is dextral. The initiation of the Lough Neagh pull-apart basin would have resulted in subsidence between the major en echelon controlling faults (Dooley et al. 1999) and can be dated by the age of the Mid-Paleocene lavas (61 my) that may have their greatest thickness beneath Lough Neagh.

The Upper Oligocene (Chattian) sedimentary fill around and beneath Lough Neagh dates another phase of Cenozoic fault reactivation which resulted in a deepening of the basin and the development of the diagonally arranged depocentres separated by a high (Figs. $5 \& 6$ ). The juxtaposition of the two Chattian depocentres, that together form a NNE trend, is consistent with them having been formed between two NNW-trending faults. The development of the Lough Neagh pull-apart basin, from proposed initiation in the MidPaleocene, with the formation of an area of marked subsidence (filled by lavas), to high levels of sedimentation of the Lough Neagh Group in separate depocentres in the Late Oligocene, is an example of the episodic development of pull-apart basins (Mann et al. 1983). In the Kish Bank Basin, between 6-9 km of Cenozoic movement has been estimated for the Codling Fault (Fig. 1; Jenner 1981; Dunford et al. 2001), but due to lack of mapped evidence of displacement (GSNI 1997) it is difficult to assess the amount of movement on the NNWtrending faults controlling the formation of the Lough Neagh pull-apart. 
Figure 6 summarises the different stress directions at various times during the Cenozoic from measurement of fault and cleavage directions in Upper Cretaceous chalk and Paleocene basalts and granites in NE Ireland (Kerr 1987; Millar 1990; Geoffroy et al. 1996). Geoffroy et al. (1996) recognise a syn-magmatic Paleocene event in which normal faulting and extensional strike-slip occurred, and assign the dextral offsetting of the Carlingford and Slieve Gullion intrusions to this event. An Oligocene NW-SE extensional event, recognized by Geoffroy et al. (1996), fits well with the proposed dextral movement on the bounding NNWtrending faults of the Lough Neagh pull-apart in the Late Oligocene (Fig. 6). This event may also be responsible for the formation of two small Cenozoic basins that have been mapped to the north Ireland (Fyfe et al. 1993). The Canna Basin, located SW of Skye, and a small basin located SE of Harris adjacent to the Minch Fault, contain Cenozoic sediments of Late Oligocene, Chattian age, contemporaneous with that of the Lough Neagh Group (Wilkinson et al. 1980; Fyfe et al. 1993).

In summary, the Cenozoic Lough Neagh pull-apart basin was initiated in the Mid-Paleocene by dextral movement on segmented right-stepping NNW-trending faults. The formation of this basin provided additional accommodation space for the accumulation of a thick succession of Paleocene lavas. Continuing movement in the Late Oligocene enabled the accumulation of thick clays and lignites of the Lough Neagh Group. The ages of the igneous and sedimentary fill date these episodes of the pull-apart evolution. Regionally, the fault movements that caused initiation and development of the Cenozoic Lough Neagh pull-apart basin were the result of interaction of stresses related to the opening of the North Atlantic with those associated with collision of Africa and Europe and the formation of the Alps (Fig. $6)$.

\section{Implications}

The model presented in this paper proposes that initiation of the Lough Neagh pull-apart basin occurred just prior to, or coincident with, eruption of the Lower Basalt Formation. This associates its formation with the eruption of thick flood basalts of the Antrim Lava Group, and prompts the question as to whether the two are linked. Walker (1995) noted the misalignment between the NW-trending volcanic axis, marked by a high density of mapped dykes and rhyolites east of Lough Neagh, and the axis of maximum subsidence, the site of the thickest lavas and pull-apart basin (Fig. 4). It is suggested here that the reactivation of the NNW-trending faults that formed the pull-apart may also have acted as a focus for fissure eruption of the lavas within the context of the opening of the North Atlantic Ocean. 
Contemporary basin subsidence, marking the early stage of development of the pull-apart, provided accommodation space for the lavas flowing from the fissures. Thus, the anomalous configuration between the volcanic axis and the axis of maximum subsidence (Walker 1995) can be explained by the position of the NNW trending fault east of Lough Neagh in relation to the pull-apart basin sited at Lough Neagh (Fig. 4).

It has been suggested that intrusion of the Lundy Granite at the end of the Mid-Paleocene $(58.7 \pm 1.6 \mathrm{Ma}$; Thorpe et al. 1990) may have been associated with Early Cenozoic movement on the Sticklepath-Lustleigh Fault (Fig. 6; Holloway \& Chadwick 1986; Lake \& Karner 1987; Arthur 1989). Cunningham et al. (2004) describe a high intensity magnetic anomaly adjacent to the Codling Fault in the Kish Bank Basin and interpret it as an igneous intrusion. They suggest that the position of the proposed intrusion, its axis parallel to the Codling Fault, and its shape, point to it being syntectonic and link its formation with that of movement on the Codling Fault during the Paleocene. In NE Ireland the Slieve Gullion (56.5 $\pm 1.3 \mathrm{Ma})$ and Carlingford (61.4 $\pm 0.8 \mathrm{Ma}$ ) intrusive complexes (dates from Gamble et al. 1999; Mitchell et al. 1999) are located on the NNW-trending fault zone, south of Lough Neagh, that controlled the development of the Lough Neagh pull-apart (Fig. 3). It is suggested here that emplacement of these intrusive complexes is due to the presence of this active fault zone and may date movements on these faults (Figs. $3 \& 6$ ).

\section{Conclusions}

This paper describes the characteristics and development of the Lough Neagh pull-apart basin during the Cenozoic and draws the following conclusions:

- The Lough Neagh pull-apart has many of the characteristics seen in pull-apart basins worldwide;

- Initiation of the pull-apart took place in the Mid-Paleocene (61 Ma), coinciding with, or just prior to, extrusion of the Lower Basalt Formation;

- The pull-apart was formed by dextral movement on right-stepping NNW-trending faults;

- Reactivation of NNW-trending faults was the possible cause of emplacement of Slieve Gullion and Carlingford igneous complexes whose ages may date movements on these faults;

- Late Oligocene reactivation of the NNW-trending faults led to deepening and enlargement of the basin enabling deposition of the Lough Neagh Group; 
- The Mid-Paleocene movement of the faults that initiated formation of the Lough Neagh pull-apart basin also initiated eruption of the Antrim Plateau Lavas in this intraplate setting.

\section{Acknowledgements}

The author wishes to thank Kevin Smith whose example, in his infectious enthusiasm, many wide ranging discussions over the years, and his encouragement, stimulated the ideas that led to this paper. Many thanks also go to Don Cameron who expertly edited an early draft of the manuscript and Derek Reay of GSNI who supplied additional data and advice. Helpful suggestions and encouragement from Derek Ritchie, Ken Hitchen and other colleagues is appreciated. Finally, the paper was improved greatly by helpful comments of two external referees David Naylor and John Walsh. This paper is published by permission of the Director, British Geological Survey (NERC).

\section{References}

ANDERSON, T.B., PARNELL J. \& RUFFELL, A.H. 1995. Influence of basement on the geometry of Permo-Triassic basins in the northwest British Isles. In Boldy, S.A.R. (ed.) Permian and Triassic rifting in Northwest Europe. The Geological Society, London, Special Publications, 91, 103-122.

ANDERSON, T.B., JOHNSTON, T.P. \& MITCHELL, W.I. 2004. Basement structure and the terrane model. In Mitchell, W, I. (ed). The Geology of Northern Ireland - Our Natural Foundation. (Second Edition). Geological Survey of Northern Ireland, Belfast, 1-8.

ARTHUR, M.J. 1989. The Cenozoic evolution of the Lundy Pull-Apart Basin into the Lundy Rhomb Horst. Geological Magazine, 126 (2), 187-198.

AYDIN, A. \& NUR, A. 1982. Evolution of pull-apart basins and their scale independence. Tectonophysics, 1, 91-105.

BARTHOLOMEW, I.D., PETERS, J.M. \& POWELL, C.M. 1993. Regional structural evolution of the North Sea: oblique slip and the reactivation of basement lineaments. In Parker, J.R. (ed.) Petroleum Geology of Northwest Europe: Proceedings of the 4th Conference. The Geological Society, London. 1109-1122.

BRISTOW, C.M. \& ROBSON, J.L. 1994. Palaeogene basin development in Devon. Transactions of the Institution of Mining and Metallurgy (Section B: Applied earth sciences), 103, B163-B174. 
BRITISH GEOLOGICAL SURVEY. 1997. Colour shaded relief gravity anomaly map of Britain, Ireland and adjacent areas. In Smith, I.F. \& Edwards, I.W.F. (compilers). 1:1 500000 scale. Keyworth, Nottingham, United Kingdom: British Geological Survey.

CARRUTHERS, R.M., CORNWELl, J.D., TURNBUlL, G., WALKER, A.S.D. \& BENNETT, J.R.P. 1987. Interpretation of the Bouguer gravity anomaly data for Northern Ireland. Regional Geophysics Research Group. British Geological Survey. Report No. $R G 87 / 5$.

CUNNINGHAM, M.J.M., PHILLIPS, W.E.A. \& DENSMORE, A.L. 2004. Evidence for Cenozoic tectonic deformation in SE Ireland and near offshore. Tectonics, 23, No. 6, TC6002.

DOOLEY, T., MCCLAY, K. \& BONORA, M. 1999. 4D evolution of segmented strike-slip fault systems: applications to NW Europe. In Fleet, A.J. \& Boldy, S.A.R. (eds) Petroleum Geology of Northwest Europe: Proceedings of the 5th Conference. The Geological Society, London. 215-225.

DUNFORD, G.M., DANCER, P.N. \& LONG, K.D. 2001. Hydrocarbon potential of the Kish Bank Basin: integration within a regional model for the Greater Irish Sea Basin. In Shannon, P.M., Haughton, P.D.W. \& Corcoran, D.V. (eds). The Petroleum Exploration of Ireland's Offshore Basins. The Geological Society, London, Special Publications, 188, 135-154.

FLOYD, J.D. 1994. The derivation and definition of the 'Southern Upland Fault': a review of the Midland Valley - Southern Uplands terrane boundary. Scottish Journal of Geology, 30 (1), 51-62.

FYFE, J.A., LONG, D. \& EVANS, D. 1993. United Kingdom offshore regional report: the geology of the Malin-Hebrides sea area. London: HMSO for the British Geological Survey.

GAMBLE, J.A., WYSOCZANSKI, R.J. \& MEIGHAN, I.G. 1999. Constraints on the age of the British Tertiary Volcanic Province from ion microprobe U-Pb (SHRIMP) ages for acid igneous rocks from NE Ireland. Journal of the Geological Society, London, 156, 291-299. 
GEOFFROY, L., BERGERAT, F. \& ANGELIER, J. 1996. Brittle tectonism in relation to the Palaeogene evolution of the Thulean/NE Atlantic domain: a study in Ulster. Geological Journal, 31, 259-269.

GSNI. (GEOLOGICAL SURVEY OF NORTHERN IRELAND). 1985. Armagh. Northern Ireland Sheet 47. Solid Geology. 1:50 000 Series. Keyworth, Nottingham; British Geological Survey.

GSNI. (GEOLOGICAL SURVEY OF NORTHERN IRELAND). 1994. Antrim. Northern Ireland Sheet 28. Solid and Drift Geology. 1:50 000. Keyworth, Nottingham; British Geological Survey.

GSNI. (GEOLOGICAL SURVEY OF NORTHERN IRELAND). 1997. Northern Ireland. Solid Geology (Second Edition). 1:250 000. Keyworth, Nottingham; British Geological Survey.

HOLLOWAY, S. \& CHADWICK, R.A. 1986. The Sticklepath-Lustleigh fault zone: Tertiary sinistral reactivation of a Variscan dextral strike-slip fault. Journal of the Geological Society, London, 143, 447-452.

ILLING, L.V. \& GRIFFITH, A.E. 1986. Gas prospects in the 'Midland Valley' of Northern Ireland. In Brooks, J., Goff, J.C. \& Van Hoorn, B. (eds). Habitat of Palaeozoic Gas in NW Europe. The Geological Society, London, Special Publications, 23, 73-84.

JENNER, J.K. 1981. The Structure and Stratigraphy of the Kish Bank Basin. In Illing, L.V. \& Hobson, G.D. (eds) Petroleum Geology of the Continental Shelf of North-West Europe: Proceedings of the 2nd Conference. The Geological Society, London. 426431.

KERR, I.D.V. 1987. Basement/Cover Structural Relationships in the North Antrim Area, Ireland. Unpublished PhD thesis, The Queen's University of Belfast.

LAKE, S.D. \& KARNER G.D. 1987. The structure and evolution of the Wessex Basin, southern England: an example of inversion tectonics. Tectonophysics, 137, 347-378.

MANN, P., HEMPTON, P.R., BRADLEY, D.C. \& BURKE, K. 1983. Development of pullapart basins. Journal of Geology, 91, 529-554.

MANNING, P.I., ROBBIE, J.A. \& WILSON, H.E. 1970. Geology of Belfast and the Lagan Valley. British Geological Survey Memoir, Government of Northern Ireland, Ministry of Commerce. HMSO, Belfast. 
MCCAFFREY, R.J. \& MCCANN, N. 1992. Post-Permian basin history of northeast Ireland. In Parnell, J. (ed). Basins on the Atlantic Seaboard: Petroleum Geology, Sedimentology and Basin Evolution. The Geological Society, London, Special Publications, 62, 277-290.

MCCANN, N. 1991. Subsurface geology of the Lough Neagh-Larne Basin, Northern Ireland. Irish Journal of Earth Sciences, 11, 53-64.

MILLAR, G. 1990. Fracturing in the NW Carboniferous Basin, Ireland. Unpublished PhD thesis, The Queen's University of Belfast.

MITCHELL, W. I., COOPER, M.R., HARDS, V.L. \& MEIGHAN, I.G. 1999. An occurrence of silicic volcanic rocks in the early Palaeogene Antrim Lava Group of Northern Ireland. Scottish Journal of Geology, 35, 179-185.

MITCHELL, W. I. 2004. Late Palaeogene (Oligocene) Sedimentary Basins. In Mitchell, W, I. (ed). The Geology of Northern Ireland - Our Natural Foundation. (Second Edition). Geological Survey of Northern Ireland, Belfast, 199-204.

NAYLOR, D. 1992. The post-Variscan history of Ireland. In PARnELl, J. (ed). Basins on the Atlantic Seaboard: Petroleum Geology, Sedimentology and Basin Evolution. Geological Society, London, Special Publications, 62, 255-275.

NAYLOR, D., PHILCOX, M.E. \& CLAYTON, G. 2003. Annaghmore-1 and Ballynamullan1 wells, Larne-Lough Neagh Basin, Northern Ireland. Irish Journal of Earth Sciences, 21, 47-69.

OUDMAYER, B.C. \& DE JAGER, J. 1993. Fault reactivation and oblique-slip in the Southern North Sea. In PARKeR, J.R. (ed) Petroleum Geology of Northwest Europe: Proceedings of the 4th Conference. The Geological Society, London. 1281-1290.

PARNELL, J., SHUKLA, B. \& MEIGHAN, I.J. 1989. The lignite and associated sediments of the Tertiary Lough Neagh Basin. Irish Journal of Earth Sciences, 10, 67-88.

PENN, I. E., HOLLIDAY, D.W., KIRBY, G.A., KUBALA, M., SOBEY, R.A., MITCHELL, W.I., HARRISON, R.K. \& BECKINSALE, R.D. 1983. The Larne No. 2 Borehole: discovery of a new Permian volcanic centre. Scottish Journal of Geology, 19, 333346. 
PHARAOH, T.C., MORRIS, J.H., LONG, C.B. \& RYAN, P.D. (Compilers). 1996. Tectonic map of Britain, Ireland and adjacent areas, 1:1 500 000. Keyworth, Nottingham. British Geological Survey.

PHILLIPS, W.E.A. 2001. The Grampian Orogeny. In Holland, C.H. (ed). The Geology of Ireland. Dunedin Academic Press, Edinburgh, 47-71.

PRESTON, J. 2001. Tertiary Igneous Activity. In Holland, C.H. (ed). The Geology of Ireland. Dunedin Academic Press, Edinburgh, 353-373.

READ, W.A. 1988. Controls on Silesian sedimentation in the Midland Valley of Scotland. In Besly, B.M. \& Kelling, G. (eds). Sedimentation in a Synorogenic Basin Complex: the Upper Carboniferous of Northwest Europe. Blackie, Glasgow and London, 222241.

REAY, D. M. 2004. Geophysics and Concealed Geology. In Mitchell, W. I. (ed). The Geology of Northern Ireland - Our Natural Foundation. (Second Edition). Geological Survey of Northern Ireland, Belfast, 227-248.

REIJS, J. \& MCCLAY, K. 2003. The Salina del Fraile pull-apart basin, northwest Argentina. In Storti, F., Holdsworth, R.E. \& Salvini, F. (eds). Intraplate Strike-Slip Deformation Belts. Geological Society, London, Special Publications, 210, 197-209.

RITCHIE, J.D., JOHNSON, H., BROWNE, M.A.E. \& MONAGHAN, A.A. 2003. Late Devonian-Carboniferous tectonic evolution within the Firth of Forth, Midland Valley; as revealed from 2D seismic reflection data. Scottish Journal of Geology, 39 (2), 121-134.

RUFFELL, A \& CAREY, P.F. 2001. The northwestwards continuation of the Sticklepath Fault: Bristol Channel, SW Wales, St. Georges Channel and Ireland. Geoscience in south-west England, 10, 134-141. Proceedings of the Ussher Society.

SHELTON, R. 1997. Tectonic evolution of the Larne Basin. In: Meadows, N.S., Trueblood, S.P., Hardman, M. \& Cowan, G. (eds). Petroleum Geology of the Irish Sea and adjacent areas. Geological Society, London, Special Publications, 124, 113-133.

SMITH, K. 2004. The North Sea Silverpit Crater: impact structure or pull-apart basin? Journal of the Geological Society, London, 161, 593-602.

SYLVESTER, A.G. 1988. Strike-slip faults. Geological Society of America Bulletin, 100,1666-1703. 
THOMPSON, P. 1985. Dating the British Tertiary Igneous Province in Ireland by the ${ }^{40} \mathrm{Ar}-$ ${ }^{39}$ Ar stepwise degassing method. Unpublished Ph.D thesis. University of Liverpool.

THORPE, R.S., TINDLE, A.G. \& GLEDHILL, A. 1990. The petrology and origin of the Tertiary Lundy Granite (Bristol Channel, UK). Journal of Petrology, 31, 6, 13791406.

TOMKEIEFF, S.I. 1964. Petrochemistry and petrogenesis of the British Tertiary igneous province. In Advancing Frontiers in Geology and Geophysics, Hyderabad.

WALKER, G.P.L. 1995. Flood basalts versus central volcanoes and the British Tertiary Volcanic Province. In Le Bas, M.J. (ed). Milestones in Geology. Geological Society, London, Memoir, 16, 195-202.

WILKINSON, G.C., BAZLEY, R.A.B. \& BOULTER, M.C. 1980. The geology and palynology of the Oligocene Lough Neagh Clays, Northern Ireland. Journal of the Geological Society, London, 137, 65-75.

WILLIAMS, G.A., TURNER, J.P. \& HOLFORD, S.P. 2005. Inversion and exhumation of the St. George's Channel basin, offshore Wales, UK. Journal of the Geological Society, London, 161, 1-14.

WILSON, H.E. 1972. Regional Geology of Northern Ireland. Geological Survey of Northern Ireland. HMSO, Belfast.

WILSON, H.E., REID, R.E.H., PARNELL, J. \& SMITH, R.A. 2001. Permian and Mesozoic. In Holland, C.H. (ed). The Geology of Ireland. Dunedin Academic Press, Edinburgh.

ZIEGLER, P.A. 1987. Late Cretaceous and Cenozoic intra-plate compressional deformations in the Alpine foreland - a geodynamic model. Tectonophysics, 137, 389-420.

ZIEGLER, P.A. 1990. Geological Atlas of Western and Central Europe. (2nd Edition) Shell Internationale Petroleum Maatschappij B.V. 


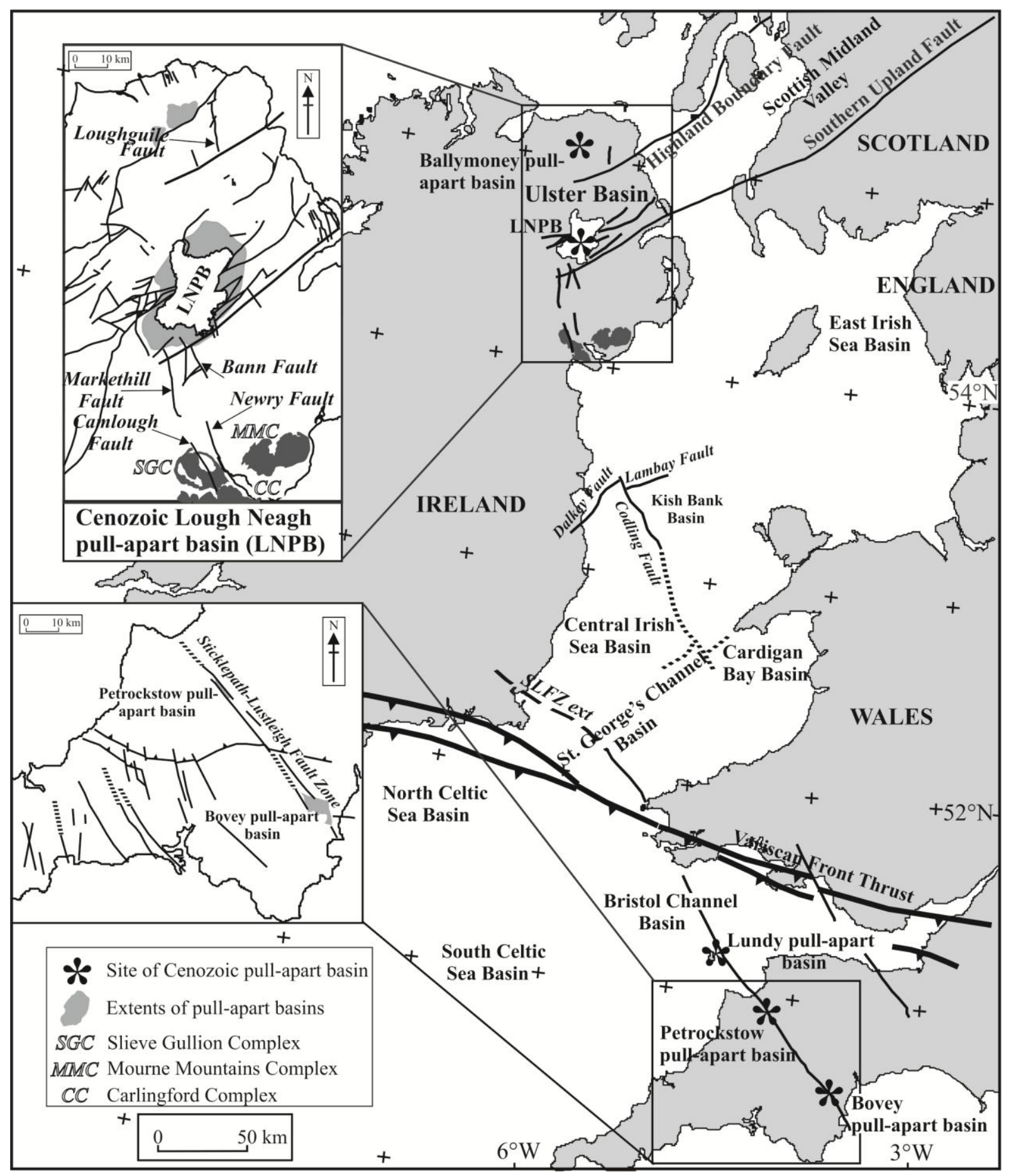

Figure 1. The Lough Neagh pull-apart basin in its regional setting (Compiled from Illing \& Griffith 1986; Bristow \& Robson 1994; Pharaoh et al. 1996; GSNI 1997; Dunford et al. 1999; Ruffell \& Carey 2001) 


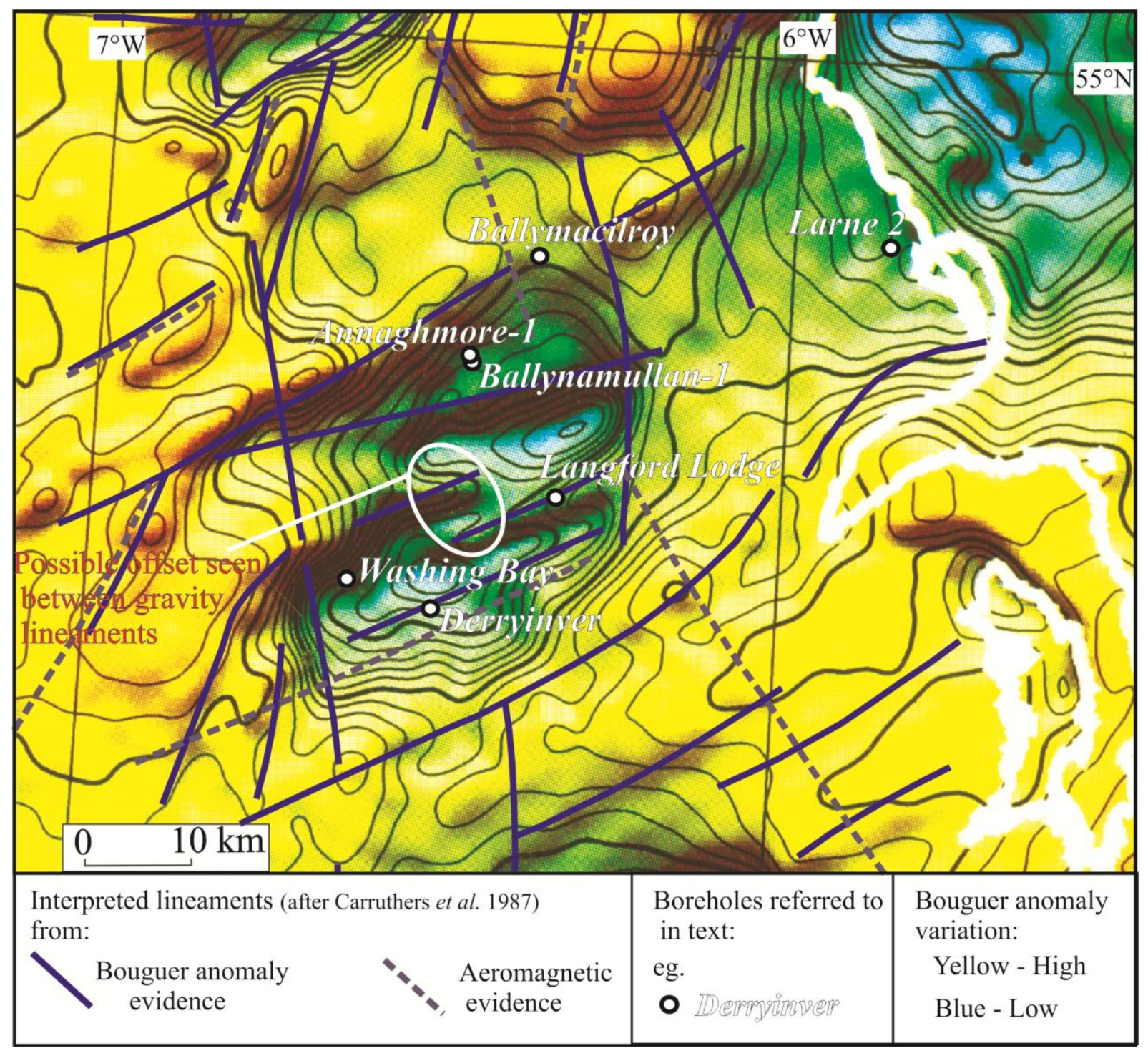

Figure 2. Shaded relief Bouguer gravity map over the Lough Neagh Basin showing location of gravity and magnetic lineaments (compiled from Carruthers et al. 1987; BGS 1997). 


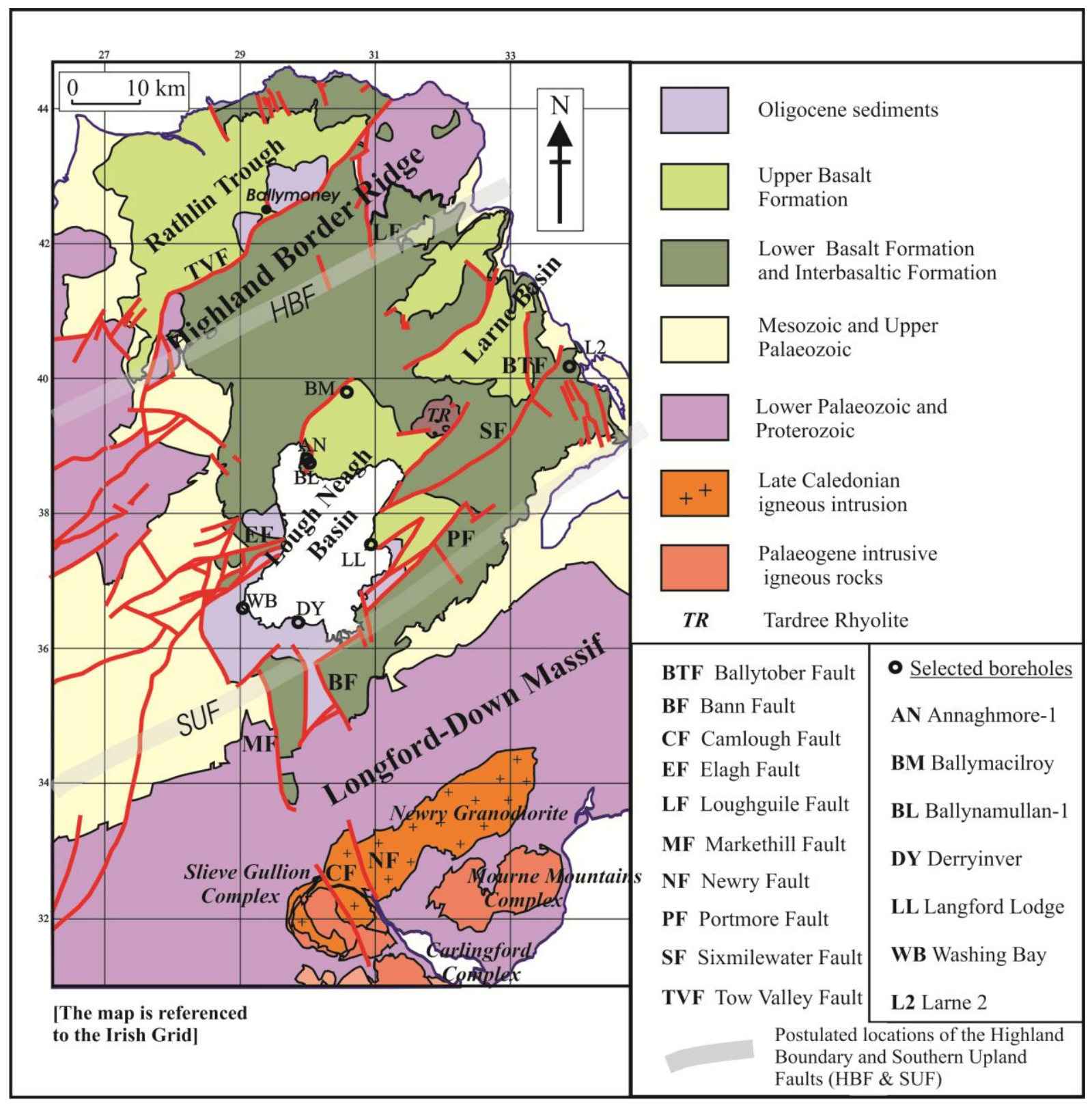

Figure 3. Simplified geological map of north-east Ireland (Compiled from GSNI 1997). 


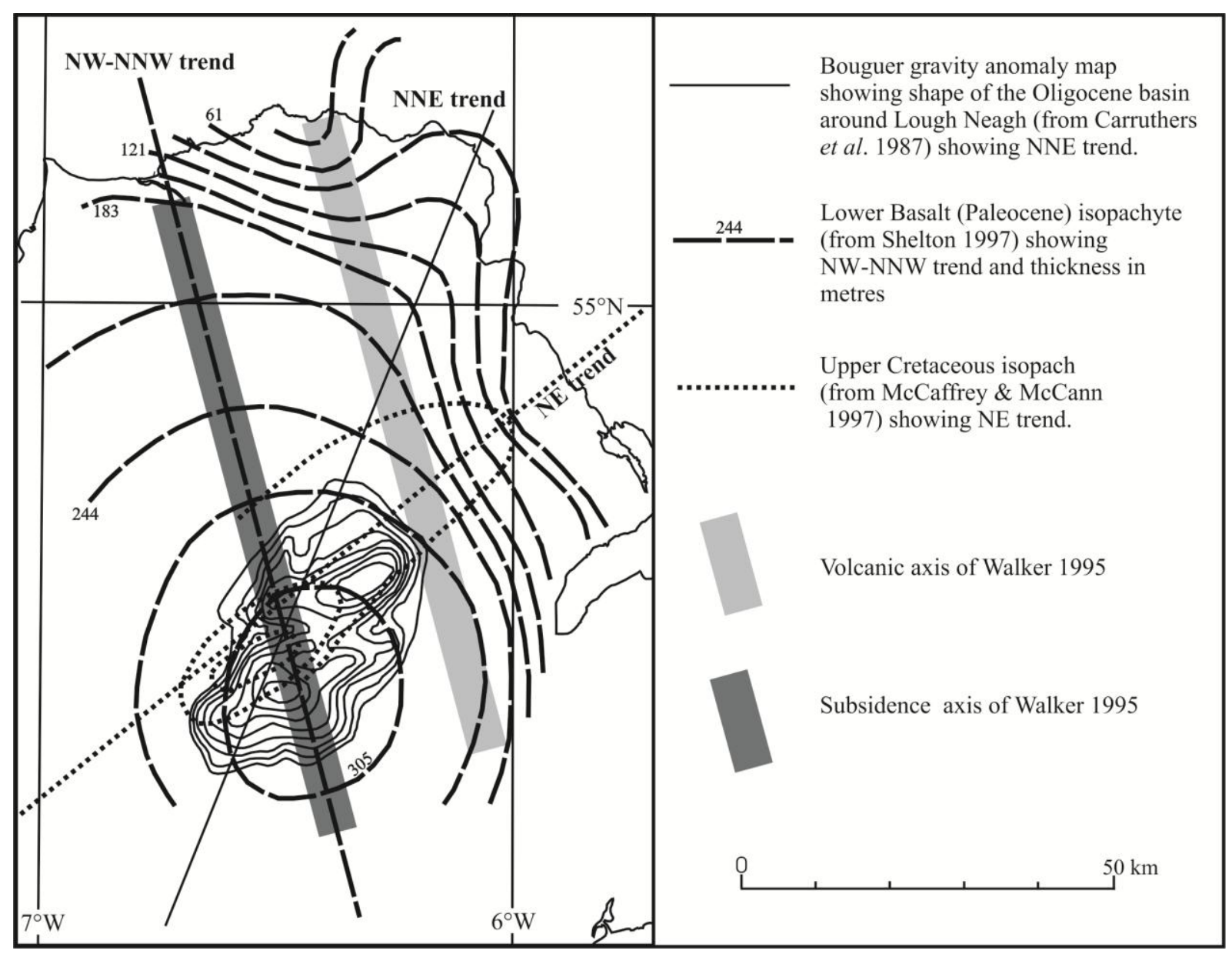

Figure 4. Isopachs of the Upper Cretaceous Chalk and the Paleocene Lower Basalt, and

Bouguer gravity anomaly contours in the Lough Neagh region illustrating change in basin trends through time. 


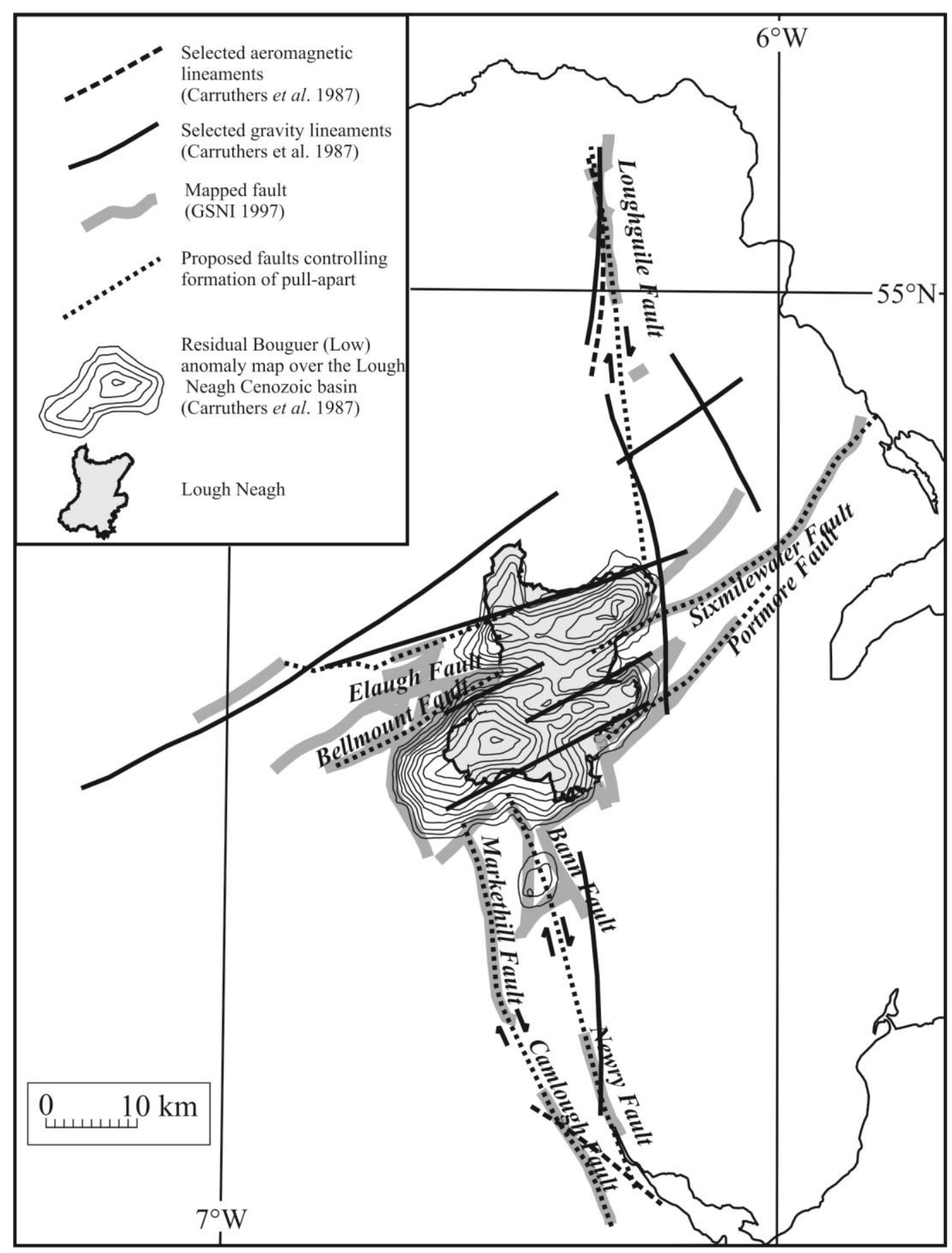

Figure 5. The Lough Neagh pull-apart basin - main controlling faults and their inferred continuations from selected mapped aeromagnetic and gravity lineaments. 


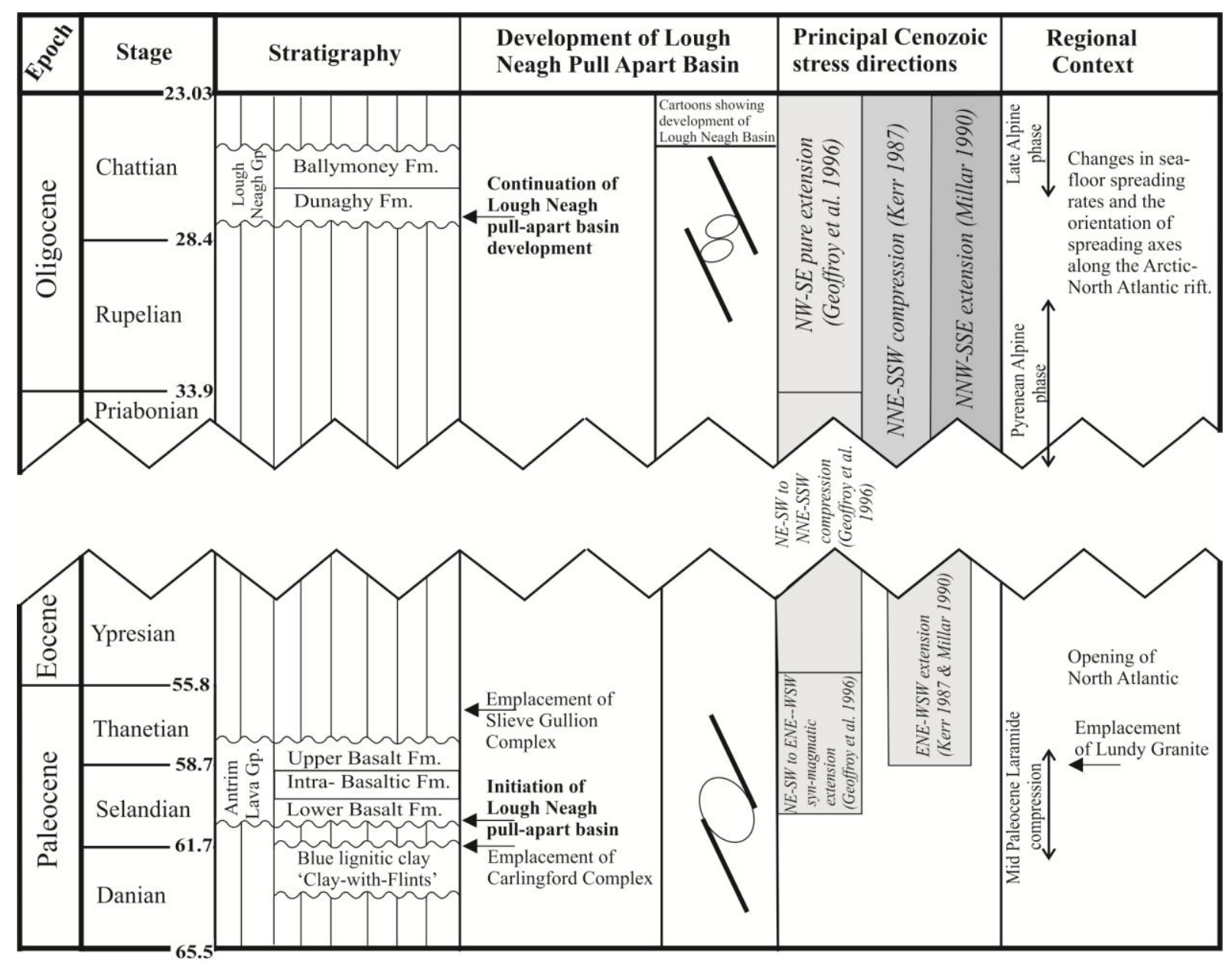

Figure 6. Summary of stratigraphy, development of the Lough Neagh pull-apart basin, Cenozoic stress directions measured in NE Ireland and regional events. Compiled from Ziegler (1987, 1990); Geoffroy et al. (1996); Shelton (1997) (after Kerr (1987); Millar (1990)); Mitchell (2004). 